\title{
Financial Analysis of Startups Company PT. Limatra Innovation of Subang Honey Pineapple Beverage
}

\author{
Wisnu Harinugroho', Rhian Indradewa', Tantri Yanuar Rahmat Syah, \\ Ketut Sunaryanto 4 \\ ${ }^{1,2,3,4}$ Department Management, Faculty Economic and Business, Esa Unggul University, Jakarta - Indonesia \\ Corresponding Author: Wisnu Harinugroho
}

\begin{abstract}
Background - Pineapple is one of the most popular types of fruit. In addition to delicious fruit, pineapple fruit also has a very high vitamin $\mathrm{C}$ content. With a high level of community mobility and practical reasons, many people turn to packaged fruit juice drinks. PT Limatra is a startups company engaged in the trading business that sells various packaged fruit juices, with the product name "NasNas", with the main ingredient being pineapple from the Subang area, West Java. The product is not only original pineapple juice but also has a variety of flavors. As a start-up company, investment considerations are needed, which are useful for making decisions in the short and long term, financial planning is one important aspect for business continuity.

Method - Using elements of financial planning, financial statement projections, investment feasibility analysis, and ratios for financial performance analysis.
\end{abstract}

Result - Investment analysis can assist management in making strategic decisions, both short term and long term.

Keywords - Investment, Fruit Juice Drink, Financial Analysis, Startups, Financial Modelling, Strategic Financial, Business Plan.

\section{INTRODUCTION}

Pineapple is one of the most popular types of fruit. In addition to delicious fruit, pineapple fruit also has a very high vitamin $\mathrm{C}$ content. With a high level of community mobility and for practical reasons, many people turn to packaged fruit juice drinks. PT Limatra is a startups company engaged in the trading business that sells various packaged fruit juices, with the product name "NasNas", with the main ingredient being honey pineapple from the Subang area, West Java. The product is not only original pineapple juice but also has a variety of flavors. As a start-up company, a feasibility analysis on investment is needed, which is useful for management in making shortterm and long-term strategic decisions, financial planning is one important aspect for business continuity. An investment plan can also be used as a basis for making a decision to accept or reject an unprofitable investment. For Investors, it is very important to know and study the Startup Potential [1]. Financial planning is also one of the important aspects for company sustainability [2]. Companies also need to create and plan financial strategies, especially investment strategies [3].

\section{MATERIAL \& METHOD}

As a start-up company, PT Limatra has challenges in creating superior value for customers and improving financial performance [4], therefore PT Limatra really needs to have a goal to represent the results of a predetermined strategy. These goals must be quantitative, measurable, achievable, and in accordance with the company's vision and mission. Long-term goals can help companies provide direction, 
Wisnu Harinugroho et.al. Financial analysis of startups company PT. Limatra innovation of Subang honey pineapple beverage.

focus coordination, provide the basis for effective planning and control activities.
The financial objectives of PT Limatra are as follows:

Table 2.1

\begin{tabular}{|l|l|}
\hline Period & Financial Objectives \\
\hline \multirow{3}{*}{$\begin{array}{l}\text { Short-term } \\
\text { (1-3 Years) }\end{array}$} & $\begin{array}{l}\text { Competitive pricing compared to competitors, in order to maximize sales } \\
\text { Get investors to increase the company's capital (30\%) in addition to the founder's funds } \\
\text { Create product brand awareness at the beginning } \\
\text { Minimize costs, especially operational costs and employee costs }\end{array}$ \\
\hline $\begin{array}{l}\text { Medium-term } \\
\text { (3-5 Years) }\end{array}$ & $\begin{array}{l}\text { Achieve payback period in year 3 } \\
\text { Optimization of revenue (bypassing BEP points) }\end{array}$ \\
\hline \multirow{2}{*}{$\begin{array}{l}\text { Long-term } \\
\text { More than 5 Years }\end{array}$} & $\begin{array}{l}\text { Achieve stable net profit } \\
\text { Increased revenue due to the expansion carried out } \\
\end{array}$ \\
\hline
\end{tabular}

Source: Author 2021

And the targets for realizing the financial goals of PT Limatra are as follows:

Table 2.2

\begin{tabular}{|l|l|}
\hline Period & Financial Targets \\
\hline $\begin{array}{l}\text { Short-term } \\
\text { (1-3 Years) }\end{array}$ & $\begin{array}{l}\text { Get investors in the form of shares owned by the company } \\
\text { Allocate a larger marketing and promotion budget } \\
\text { Optimization of the initial cost, in order to create a competitive price }\end{array}$ \\
\hline Period & Financial Targets \\
\hline $\begin{array}{l}\text { Medium-term } \\
\text { (3-5 Years) }\end{array}$ & $\begin{array}{l}\text { Increasing the company's liquidity, namely the company's ability to meet its short-term obligations exceeding 150\% } \\
\text { Increased solvency of the company, namely the company's ability to fulfill all its obligations less than 30\% } \\
\text { Increasing the company's profitability, namely the company's ability to generate a profit of at least 15\% }\end{array}$ \\
\hline $\begin{array}{l}\text { Long-term } \\
\text { More than 5 Years }\end{array}$ & Achieve optimal investment feasibility, in order to increase the confidence of investors to invest \\
\hline
\end{tabular}

Source: Author 2021

The financial elements used by PT Limatra in financial planning in accordance with the company's financial conceptual framework are income planning, investment policy planning, company operating expenses and costs planning, capital requirements planning, and company operating financing planning (Gansel,
2005). This financial planning will be the foundation for the company's financial strength so that the company's goals to get profits that are always growing can be realized [6].

The financial planning framework of PT Limatra is shown in Figure 2.1 as follows:

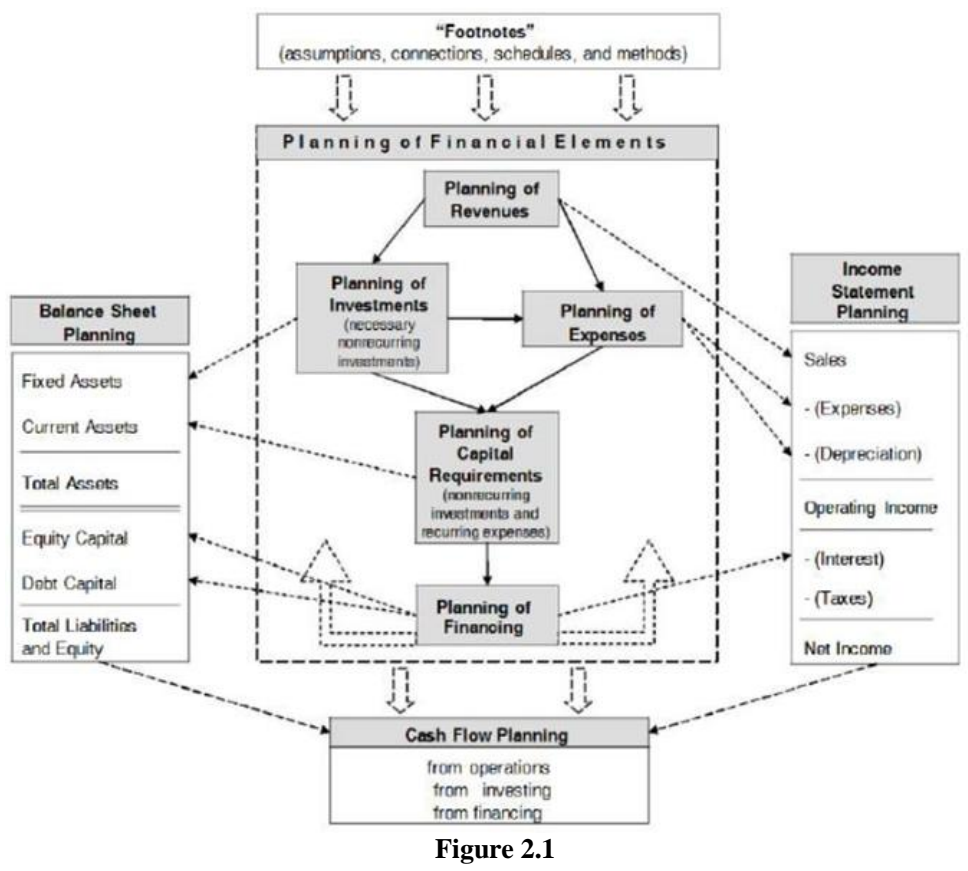


Wisnu Harinugroho et.al. Financial analysis of startups company PT. Limatra innovation of Subang honey pineapple beverage.

\section{RESULT \& DISCUSSION}

The financial planning element departs from the company's activities which consist of three main functions, namely the marketing function, operational function, and human resources function.

\begin{tabular}{|c|c|c|c|c|c|}
\hline $\begin{array}{c}\text { Sales } \\
\text { Projection }\end{array}$ & 1st year & 2nd year & 3rd year & 4th year & 5th year \\
\hline \multicolumn{6}{|l|}{ Unit Sold } \\
\hline Mass Product Original & 604,800 & 967,680 & $1,548,288$ & $2,477,261$ & $3,963,617$ \\
\hline Mass Product Mix & 151,200 & 241,920 & 387,072 & 619,315 & 990,904 \\
\hline Family Pack $1 L$ & - & - & 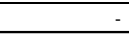 & - & 198,181 \\
\hline Total & 756,000 & $1,209,600$ & $1,935,360$ & $3,096,576$ & $5,152,702$ \\
\hline \multicolumn{6}{|l|}{ Price / Unit (Rp) } \\
\hline Mass Product Original & 7,000 & 7,000 & 7,350 & 7,350 & 7,350 \\
\hline Mass Product Mix & 7,500 & 7,500 & 7,875 & 7,875 & 7,875 \\
\hline Family Pack $1 L$ & - & - & - & - & 12,500 \\
\hline \multicolumn{6}{|l|}{ Total Sales / Type (Rp) } \\
\hline Mass Product & $4,233,600,000$ & $6,773,760,000$ & $11,379,916,800$ & $18,207,866,880$ & $29,132,587,008$ \\
\hline \begin{tabular}{|l|} 
Mass Product Mix \\
\end{tabular} & $1,134,000,000$ & $1,814,400,000$ & $3,048,192,000$ & $4,877,107,200$ & $7,803,371,520$ \\
\hline Family Pack $1 L$ & - & - & - & - & $2,477,260,800$ \\
\hline Total Sales (Rp) & $5,367,600,000$ & $8,588,160,000$ & $14,428,108,800$ & $23,084,974,080$ & $39,413,219,328$ \\
\hline
\end{tabular}

PT Limatra's revenue plan is calculated to be an annual target where sales estimates are influenced by several factors, namely economic conditions, target market, market constraints and growth, consumer demographics, competitors and changes in strategy. In accordance with table 3.1, PT
Limatra's five-year revenue plan consists of original products $(250 \mathrm{ml})$, flavor mix products $(250 \mathrm{ml})$, and in the fifth year a $1 \mathrm{~L}$ family pack product.

The HPP costs required to produce the product are in accordance with table 3.2 below:

Table 3.2

\begin{tabular}{|c|c|c|c|c|c|}
\hline $\begin{array}{c}\text { COGS } \\
\text { Projection }\end{array}$ & 1st year & 2nd year & 3rd year & 4th year & 5th year \\
\hline \multicolumn{6}{|l|}{ COGS / Unit (Rp) } \\
\hline Mass Product Original & 3,230 & 3,230 & 3,392 & 3,392 & 3,392 \\
\hline Mass Product Mix & 3,780 & 3,780 & 3,969 & 3,969 & 3,969 \\
\hline Family Pack $1 L$ & 7,500 & 7,500 & 7,875 & 7,875 & 7,875 \\
\hline \multicolumn{6}{|l|}{ Unit Sold } \\
\hline Mass Product Original & 604,800 & 967,680 & $1,548,288$ & $2,477,261$ & $3,963,617$ \\
\hline Mass Product Mix & 151,200 & 241,920 & 387,072 & 619,315 & 990,904 \\
\hline Family Pack $1 L$ & - & - & - & - & 198,181 \\
\hline \multicolumn{6}{|l|}{ COGS / Type (Rp) } \\
\hline HPP Mass Product Original & $1,953,504,000$ & $3,125,606,400$ & $5,251,018,752$ & $8,401,630,003$ & $13,442,608,005$ \\
\hline HPP Mass Product Mix & $571,536,000$ & $914,457,600$ & $1,536,288,768$ & $2,458,062,029$ & $3,932,899,246$ \\
\hline Family Pack $1 L$ & - & - & - & - & $1,560,674,304$ \\
\hline Total COGS (Rp) & $2,525,040,000$ & $4,040,064,000$ & $6,787,307,520$ & $10,859,692,032$ & $18,936,181,555$ \\
\hline Gross Profit (Rp) & $2,842,560,000$ & $4,548,096,000$ & $7,640,801,280$ & $12,225,282,048$ & $20,477,037,773$ \\
\hline
\end{tabular}

Cost planning is a process in divided into marketing costs, operational determining how much costs will be costs and human resource costs, according incurred in the future, cost planning is to the table below.

Table 3.3

\begin{tabular}{|l|r|r|r|r|r|}
\hline \multicolumn{1}{|c|}{$\begin{array}{c}\text { Cost Projection } \\
\text { (Rp) }\end{array}$} & 1st year & 2nd year & 3rd year & 4th year & 5th year \\
\hline & & & & & \\
\hline Marketing Cost & $1,073,520,000$ & $1,717,632,000$ & $2,885,621,760$ & $4,616,994,816$ & $7,882,643,866$ \\
\hline Preoperative cost & $100,000,000$ & & - & - & - \\
\hline Operational Cost & $1,100,000,000$ & $1,155,000,000$ & $1,212,750,000$ & $1,273,387,500$ & $1,337,056,875$ \\
\hline Human Capital Cost & $1,096,216,280$ & $1,372,440,988$ & $1,956,580,514$ & $2,230,188,022$ & $3,142,889,330$ \\
\hline & & & & & \\
\hline Total Cost & $\mathbf{3 , 3 6 9 , 7 3 6 , 2 8 0}$ & $\mathbf{4 , 2 4 5 , 0 7 2 , 9 8 8}$ & $\mathbf{6 , 0 5 4 , 9 5 2 , 2 7 4}$ & $\mathbf{8 , 1 2 0 , 5 7 0 , 3 3 8}$ & $\mathbf{1 2 , 3 6 2 , 5 9 0 , 0 7 0}$ \\
\hline
\end{tabular}


Investment planning carried out by PT Limatra is in the form of investment capital expenditure or commonly abbreviated as capex, which is a number of costs incurred by the company to buy, repair, or maintain assets that can be used in the long term for the sustainability of its business.
The capital expenditure investment that PT Limatra made was in the first year when the company started operating, and in the 4th year, when the company began to expand throughout Java. The following is the plan for the purchase of PT Limatra's capex, according to table 3.4.

Table 3.4

\begin{tabular}{|c|c|c|c|c|c|}
\hline $\begin{array}{c}\text { Capital } \\
\text { Expenditure (Rp) }\end{array}$ & 1st year & 2nd year & 3rd year & 4th year & 5th year \\
\hline \multicolumn{6}{|l|}{ Fixed Asset } \\
\hline Land & $200,000,000$ & - & - & $250,000,000$ & - \\
\hline Building & $150,000,000$ & - & - & $200,000,000$ & - \\
\hline Vehicle & $400,000,000$ & - & - & $200,000,000$ & - \\
\hline Equipment & $100,000,000$ & - & - & $85,000,000$ & - \\
\hline Office Inventory & $50,000,000$ & - & - & $60,000,000$ & - \\
\hline Total & $900,000,000$ & - & - & $795,000,000$ & . \\
\hline \multicolumn{6}{|l|}{ Depretiation } \\
\hline Tanah & - & - & - & - & - \\
\hline Bangunan kantor & $15,000,000$ & $15,000,000$ & $15,000,000$ & $35,000,000$ & $35,000,000$ \\
\hline Kendaraan & $80,000,000$ & $80,000,000$ & $80,000,000$ & $120,000,000$ & $120,000,000$ \\
\hline Peralatan & $20,000,000$ & $20,000,000$ & $20,000,000$ & $37,000,000$ & $37,000,000$ \\
\hline Inventaris kantor & $10,000,000$ & $10,000,000$ & $10,000,000$ & $22,000,000$ & $22,000,000$ \\
\hline Total & $125,000,000$ & $125,000,000$ & $125,000,000$ & $214,000,000$ & $214,000,000$ \\
\hline Net Fixed Asset & $900,000,000$ & $900,000,000$ & $900,000,000$ & $1,695,000,000$ & $1,695,000,000$ \\
\hline - Accumulated Depreciation & $125,000,000$ & $250,000,000$ & $375,000,000$ & $589,000,000$ & $803,000,000$ \\
\hline = Book Value & $775,000,000$ & $650,000,000$ & $525,000,000$ & $1,106,000,000$ & $892,000,000$ \\
\hline
\end{tabular}

Planning for capital requirements, as shown in table 3.5, is useful for knowing the initial capital needed by PT Limatra to run its business activities. The efficiency level of capital planning is an effort to increase the capital that will be used to meet the needs of capital expenditure and operating expenditure [7].

From the calculation of capital requirements planning, the company's initial capital requirement to operate is $\mathrm{Rp}$. $4,269,736,280$, but for the safety of the company's operational activities, additional capital is still needed from outside investors. The composition of external capital is $30 \%$, and the composition of the founding shareholders is $70 \%$ consisting of four people. The following is a plan for the capital structure of PT Limatra.
Table 3.5

\begin{tabular}{|l|r|}
\hline \multicolumn{1}{|c|}{$\begin{array}{c}\text { Initial Capital } \\
\text { Requirement (Rp) }\end{array}$} & \multicolumn{1}{c|}{ Total } \\
\hline Operating expenditure & \\
\hline Preoperative cost & $100,000,000$ \\
\hline Marketing Cost & $1,073,520,000$ \\
\hline Operational Cost & $1,100,000,000$ \\
\hline Human Capital Cost & $1,096,216,280$ \\
\hline Total Operating expenditure & $\mathbf{3 , 3 6 9 , 7 3 6 , 2 8 0}$ \\
\hline Total Capital Expenditure & $\mathbf{9 0 0 , 0 0 0 , 0 0 0}$ \\
\hline & \\
\hline Total Initial Capital Requirement & $\mathbf{4 , 2 6 9 , 7 3 6 , 2 8 0}$ \\
\hline
\end{tabular}

Financial statement projections are needed so that the company can prepare the strategies needed from the possibilities that the company will experience over the next few years. The projections of the financial statements carried out by PT Limatra consist of projected income statements (table 3.7), projected balance sheets (table 3.8) and projected cash flow statements (table 3.9). 
Wisnu Harinugroho et.al. Financial analysis of startups company PT. Limatra innovation of Subang honey pineapple beverage.

Projected financial statements will be prepared within a period of five years.

Table 3.6

\begin{tabular}{|l|r|r|r|}
\hline \multicolumn{1}{|c|}{ Capital Structure } & Shareholding & $\begin{array}{c}\text { Price per share } \\
\text { (Rp) }\end{array}$ & \multicolumn{1}{c|}{$\begin{array}{c}\text { Total } \\
\text { (Rp) }\end{array}$} \\
\hline Founding Capital (70\%) & & & \\
\hline Saputra Tri Wardana & 1,050 & 10,000 & $1,050,000,000$ \\
\hline Bea Kahfi Arini & 1,050 & 10,000 & $1,050,000,000$ \\
\hline Dita Fryandini & 1,050 & 10,000 & $1,050,000,000$ \\
\hline Wisnu Harinugroho & 1,050 & 10,000 & $1,050,000,000$ \\
\hline Total Founding Capita & $\mathbf{4 , 2 0 0}$ & & $\mathbf{4 , 2 0 0 , 0 0 0 , 0 0 0}$ \\
\hline Investor's Capital (30\%) & & & \\
\hline Angel Investor & 1,800 & 10,000 & $1,800,000,000$ \\
\hline Total Investor's Capital & $\mathbf{1 , 8 0 0}$ & & $\mathbf{1 , 8 0 0 , 0 0 0 , 0 0 0}$ \\
\hline Total Capital & $\mathbf{6 , 0 0 0}$ & & $\mathbf{6 , 0 0 0 , 0 0 0 , 0 0 0}$ \\
\hline
\end{tabular}

Table 3.7

\begin{tabular}{|l|r|r|r|r|r|}
\hline \multicolumn{1}{|c|}{$\begin{array}{c}\text { Profit \& Loss } \\
\text { Projection (Rp) }\end{array}$} & \multicolumn{1}{|c|}{ 1st year } & \multicolumn{1}{c|}{ 2nd year } & \multicolumn{1}{c|}{ 3rd year } & 4th year & 5th year \\
\hline & & & & & \\
\hline Revenue & $5,367,600,000$ & $8,588,160,000$ & $14,428,108,800$ & $23,084,974,080$ & $39,413,219,328$ \\
\hline COGS & $2,525,040,000$ & $4,040,064,000$ & $6,787,307,520$ & $10,859,692,032$ & $18,936,181,555$ \\
\hline Gross Profit & $\mathbf{2 , 8 4 2 , 5 6 0 , 0 0 0}$ & $\mathbf{4 , 5 4 8 , 0 9 6 , 0 0 0}$ & $\mathbf{7 , 6 4 0 , 8 0 1 , 2 8 0}$ & $\mathbf{1 2 , 2 2 5 , 2 8 2 , 0 4 8}$ & $\mathbf{2 0 , 4 7 7 , 0 3 7 , 7 7 3}$ \\
\hline & & & & & \\
\hline G\&A Expenses & & & & & \\
\hline Marketing Cost & $1,073,520,000$ & $1,717,632,000$ & $2,885,621,760$ & $4,616,994,816$ & $7,882,643,866$ \\
\hline Preoperative cost & $100,000,000$ & & & - & - \\
\hline Operational Cost & $1,100,000,000$ & $1,155,000,000$ & $1,212,750,000$ & $1,273,387,500$ & $1,337,056,875$ \\
\hline Human Capital Cost & $1,096,216,280$ & $1,372,440,988$ & $1,956,580,514$ & $2,230,188,022$ & $3,142,889,330$ \\
\hline Total G\&A Expenses & $\mathbf{3 , 3 6 9 , 7 3 6 , 2 8 0}$ & $\mathbf{4 , 2 4 5 , 0 7 2 , 9 8 8}$ & $\mathbf{6 , 0 5 4 , 9 5 2 , 2 7 4}$ & $\mathbf{8 , 1 2 0 , 5 7 0 , 3 3 8}$ & $\mathbf{1 2 , 3 6 2 , 5 9 0 , 0 7 0}$ \\
\hline & & & & & \\
\hline EBITDA & $\mathbf{( 5 2 7 , 1 7 6 , 2 8 0 )}$ & $\mathbf{3 0 3 , 0 2 3 , 0 1 2}$ & $\mathbf{1 , 5 8 5 , 8 4 9 , 0 0 6}$ & $\mathbf{4 , 1 0 4 , 7 1 1 , 7 1 0}$ & $\mathbf{8 , 1 1 4 , 4 4 7 , 7 0 3}$ \\
\hline & & & & & \\
\hline Depreciation & $125,000,000$ & $125,000,000$ & $125,000,000$ & $214,000,000$ & $214,000,000$ \\
\hline Tax & & $39,165,063$ & $321,386,781$ & $855,956,576$ & $1,738,098,495$ \\
\hline & & & & & \\
\hline Net Profit & $\mathbf{( 6 5 2 , 1 7 6 , 2 8 0 )}$ & $\mathbf{1 3 8 , 8 5 7 , 9 5 0}$ & $\mathbf{1 , 1 3 9 , 4 6 2 , 2 2 5}$ & $\mathbf{3 , 0 3 4 , 7 5 5 , 1 3 4}$ & $\mathbf{6 , 1 6 2 , 3 4 9 , 2 0 8}$ \\
\hline
\end{tabular}

Table 3.8

\begin{tabular}{|c|c|c|c|c|c|}
\hline $\begin{array}{l}\text { Balance Shet } \\
\text { Projection (Rp) }\end{array}$ & 1st year & 2nd year & 3rd year & 4th year & 5th year \\
\hline \multicolumn{6}{|l|}{ ASSET } \\
\hline & & & & & \\
\hline Current Asset & $6,130,958,534$ & $6,478,516,119$ & $8,156,587,252$ & $11,363,715,692$ & $19,829,279,292$ \\
\hline Total Fixed Asset & $775,000,000$ & $650,000,000$ & $525,000,000$ & $1,106,000,000$ & $892,000,000$ \\
\hline Total Asset & $6,905,958,534$ & 7,128,516,119 & $8,681,587,252$ & $12,469,715,692$ & $20,721,279,292$ \\
\hline & & & & & \\
\hline \multicolumn{6}{|l|}{ LIABILITIES \& EQUITY } \\
\hline & & & & & \\
\hline Current Liabilities & $733,134,814$ & $1,091,834,449$ & $1,780,443,358$ & $2,808,816,664$ & $4,898,031,056$ \\
\hline Long Term Liabilities & $825,000,000$ & $550,000,000$ & $275,000,000$ & - & - \\
\hline Total Liabilities & $1,558,134,814$ & $1,641,834,449$ & $2,055,443,358$ & $2,808,816,664$ & $4,898,031,056$ \\
\hline Total Equity & $5,347,823,720$ & $5,486,681,670$ & $6,626,143,895$ & $9,660,899,028$ & $15,823,248,236$ \\
\hline Total Liabilities \& Equity & $6,905,958,534$ & $7,128,516,119$ & $8,681,587,252$ & $12,469,715,692$ & $20,721,279,292$ \\
\hline
\end{tabular}

After the net cash inflow is known, then it is calculated whether the investment project is feasible or not, by conducting an investment feasibility analysis, which is carried out to determine the prospects of a company. This is very important for investors in determining whether to invest in the company or not. The investment feasibility analysis consists of four, namely Net Present Value (NPV), Payback Period (PP), Profitability Index (PI), Internal Rate 
Wisnu Harinugroho et.al. Financial analysis of startups company PT. Limatra innovation of Subang honey pineapple beverage.

of Return (IRR) and Break Event Point (BEP), according to table 3.10.

\begin{tabular}{|c|c|c|c|c|c|}
\hline $\begin{array}{c}\text { Cash Flow } \\
\text { Projection }(\mathrm{Rp}) \\
\end{array}$ & 1st year & 2nd year & 3rd year & 4th year & 5 th year \\
\hline \multicolumn{6}{|l|}{ Cash Flow From Operating Activities } \\
\hline Retained earning & $(652,176,279.81)$ & $138,857,949.55$ & $1,139,462,224.87$ & $3,034,755,133.68$ & $6,162,349,207.95$ \\
\hline Depretiation & $125,000,000.00$ & $125,000,000.00$ & $125,000,000.00$ & $214,000,000.00$ & $214,000,000.00$ \\
\hline Accounts receivable & $(596,400,000.00)$ & $(119,280,000.00)$ & $(486,662,400.00)$ & $(1,106,155,008.00)$ & $(2,618,155,008.00$ \\
\hline Tax Receivable & $(50,500,800.00)$ & $(30,300,480.00)$ & $(54,944,870.40)$ & $(81,447,690.24)$ & $(161,529,790.46$ \\
\hline Inventory & $(252,504,000.00)$ & $(151,502,400.00)$ & $(274,724,352,00)$ & $(407,238,451.20)$ & $(807,648,952.32$ \\
\hline Prepaid expenses & $(154,000,000.00)$ & $(7,700,000.00)$ & $(8,085,000.00)$ & $(8,489,250.00)$ & $(8,913,712.50$ \\
\hline Accounts payable & $505,008,000.00$ & $303,004,800.00$ & $549,448,704.00$ & $814,476,902.40$ & $1,615,297,904.64$ \\
\hline Other Payable & $168,486,813.99$ & $43,766,835.40$ & $90,493,964.30$ & $103,280,903.22$ & $212,100,986.61$ \\
\hline Tax payable & $59,640,000.00$ & $11,928,000.00$ & $48,666,240.00$ & $110,615,500.80$ & $261,815,500.80$ \\
\hline Bank Loan & $750,000,000.00$ & $(250,000,000.00)$ & $(250,000,000.00)$ & $(250,000,000.00)$ & - \\
\hline Leasing debts & $75,000,000.00$ & $(25,000,000.00)$ & $(25,000,000.00)$ & $(25,000,000.00)$ & - \\
\hline Net Cash From Operating Activities & $(22,446,265.82)$ & $38,774,704.95$ & $853,654,510.77$ & $2,398,798,040.66$ & $4,869,316,136.72$ \\
\hline \multicolumn{6}{|l|}{ Cash Flow From Investing Activities } \\
\hline Acquisition of Fixed Assets & $(900,000,000.00)$ & - & - & $(795,000,000.00)$ & \\
\hline Net Cash From Investing Activities & $(900,000,000.00)$ & $\cdot$ & $\cdot$ & $(795,000,000.00)$ & $\cdot$ \\
\hline \multicolumn{6}{|l|}{ Cash Flow From Funding Activities } \\
\hline Capital & $6,000,000,000.00$ & - & - & - & - \\
\hline Net Cash From Funding Activities & $6,000,000,000.00$ & $\cdot$ & $\cdot$ & $\cdot$ & $\cdot$ \\
\hline Increase (Decrease) & $5,077,553,734.18$ & $38,774,704.95$ & $853,654,510.77$ & $1,603,798,040.66$ & $4,869,316,136.72$ \\
\hline Beginning & $\cdot$ & $5,077,553,734.18$ & $5,116,328,439.13$ & $5,969,982,949,89$ & $7,573,780,990.55$ \\
\hline Ending & $5,077,553,734.18$ & $5,116,328,439.13$ & $5,969,982,949,89$ & $7,573,780,990.55$ & $12,443,097,127.27$ \\
\hline
\end{tabular}

Table 3.10

\begin{tabular}{|l|r|l|l|}
\hline \multicolumn{1}{|c|}{ Analysis } & \multicolumn{1}{|c|}{ Result } & \multicolumn{1}{|c|}{ Requirements } & \multicolumn{1}{c|}{ Conclusion } \\
\hline NPV0 & $6,000,000,000$ & & \\
NPV1 & $9,408,244,279$ & NPV 1 > NPV 0 & Feasible \\
Payback Period & 4.07 & 4 Years 1 Month & Feasible \\
Profitability Index & 1.57 & PI $>1$ F & Feasible \\
IRR & $32 \%$ & $>$ From Interest rate & Feasible \\
ROI & $164 \%$ & 5th year & Feasible \\
Break Event Point & 2nd Year & Faster & Feasible \\
\hline
\end{tabular}

Financial performance analysis or what is often referred to as financial statement analysis is an analysis to measure company performance by comparing data in financial statements, namely balance sheets and income statements in a certain period. Financial ratio analysis is the most widely used method for determining an organization's strengths and weaknesses in the investment, financing, and dividend areas [8]. The financial ratios consist of liquidity, profitability, solvency and activity ratios. 
Wisnu Harinugroho et.al. Financial analysis of startups company PT. Limatra innovation of Subang honey pineapple beverage.

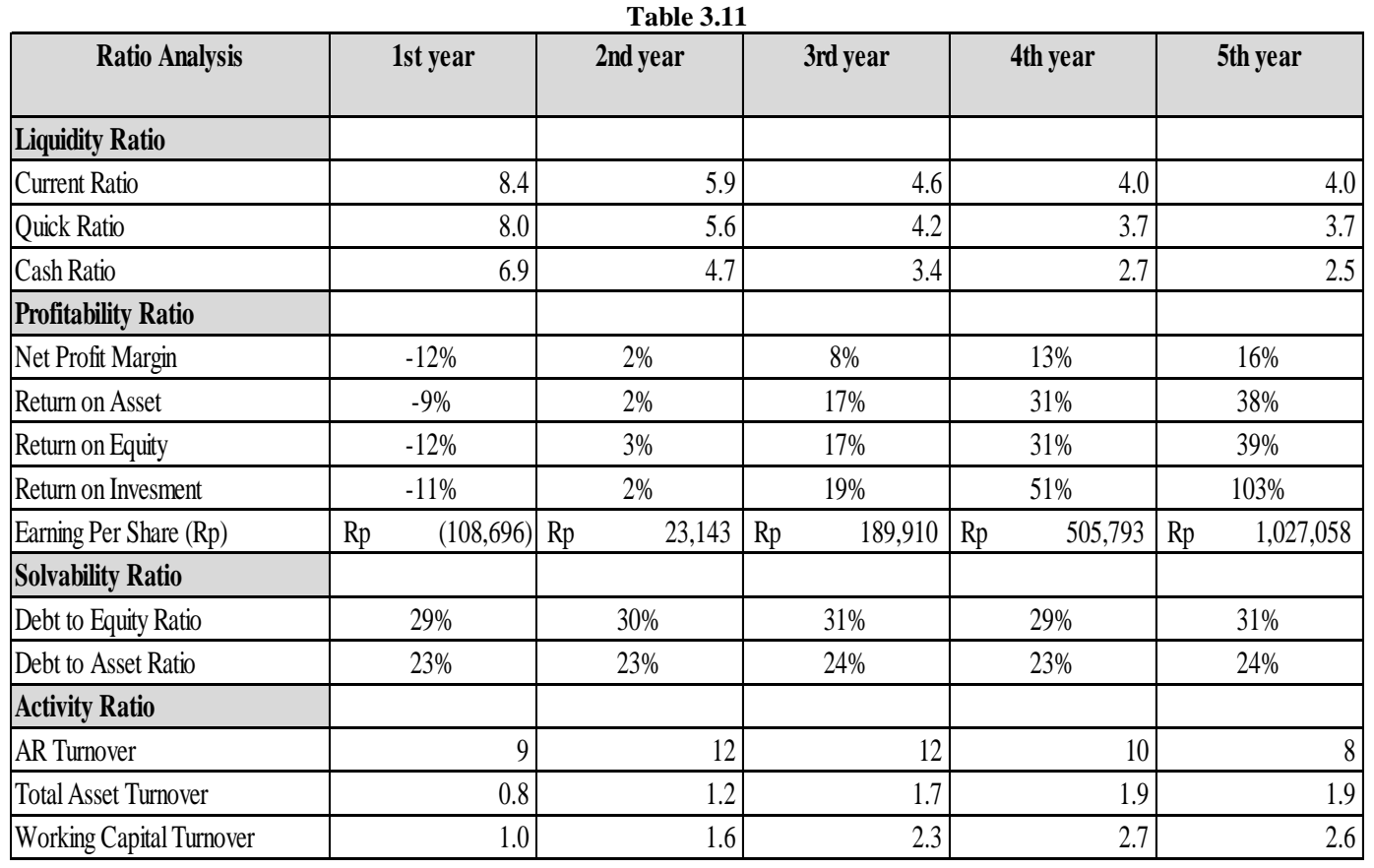

It can be seen from table 3.11, the company has good liquidity, although there is a decrease at the end of year 5, but it is not significant, and this is also due to the need for company expansion.

It can be seen in the first year that the profitability ratio of PT Limatra is still minus, this is because as a new company it is still in the stage of developing and establishing brand awareness, which requires greater promotion and marketing costs to build brand awareness. In the third year and so on, profitability starts to be positive, although not too big, but every year it looks like profitability is increasing, and reaches its peak in year 5 .

The total ratio of debt to equity and assets in the first year was quite large, due to the purchase of assets and equity which did not have additional equity because they still recorded losses in the first year. This continues until the 2nd year, only the 3rd year and so on, the company's solvency began to improve with the settlement of obligations and the increase in assets and equity owned by the company. So it can be concluded that in terms of solvency ratio, PT Limatra can be said to be solvable.

The increase and decrease in $A R$ turnover is still within reasonable limits. Meanwhile, the total asset turnover and working capital turnover increase every year, this indicates that PT Limatra has utilized its assets and capital quite well.

\section{CONCLUSION}

Based on the analysis that has been done, the investment feasibility analysis (NPV, PP, PI, IRR, ROI and BEP), and also based on the financial ratio analysis, it can be concluded that investing in PT Limatra is worth considering and is feasible.

\section{Acknowledgement: None}

\section{Conflict of Interest: None}

\section{Source of Funding: None}

\section{REFERENCES}

1. F. P. Prihambodo, T. Yanuar, R. Syah, R. Indradewa, and D. Fajarwati (2020) "Investment Feasibility Analysis in Financial Aspects of Noor Halal Minimarket Business Development Over Islamic Schools," J. Multidiscip. Acad., vol. 04, no. 03, pp. 190-193.

2. N. R. Chakim, R. Indradewa, T. Yanuar, and R. Syah (2021) "Financial Planning: Applications to Business Startups " Jamu Partnership " in Indonesia," vol. 8, no. August, pp. 483-487. 
Wisnu Harinugroho et.al. Financial analysis of startups company PT. Limatra innovation of Subang honey pineapple beverage.

3. A. Kusuma, T. Y. Syah, R. Indradewa, and D. Fajarwati, "Implementation of Financial Strategy Business Plan Arena Corner" (2021), vol. 4, no. 07, pp. 86-89.

4. S. Dror and M. Barad, "House of Strategy (HOS): From strategic objectives to competitve priorities," Int. J. Prod. Res. (2006), vol. 44, no. 18-19, pp. 3879-3895, doi: 10.1080/00207540600575779.

5. Benjamin B. Gansel, "Toward a Framework of Financial Planning in The New Venture Creation" (2005), Germany.

6. Z. Wafiq, E. Hamdi, T. Yanuar, R. Syah, and R. Indradewa, "Investment Analysis of Startups Company PT . Zaps Teknologi Service Application of BPJS" (2021), vol. 8, no. August, pp. 504-509.
7. A. Sutjiadi, T. Yanuar, R. Syah, R. Indradewa, and D. Fajarwati, "Working Capital Planning at PT Kelola Lingkungan Kita as an Effort to Increase Probability" (2020), J. Multidiscip. Acad., vol. 04, no. 06, pp. 421-425.

8. David, F. R. (2011). Strategic Management : Concepts And Cases (Thirteenth, Vol. 148). Prentice Hall.

How to cite this article: Harinugroho W, Indradewa R, Syah TYR et.al. Financial analysis of startups company PT. Limatra innovation of Subang honey pineapple beverage. International Journal of Research and Review. 2021; 8(10): 478-485. DOI: https://doi.org/10.52403/ijrr. 20211062 